\title{
PENGARUH METODE PROYEK BERBASIS PENDEKATAN SAINTIFIK TERHADAP KEMAMPUAN MOTORIK HALUS ANAK KELOMPOK B DI TK GUGUS III KECAMATAN TAMPAKSIRING
}

\author{
Ni Wayan Mulandini ${ }^{1}$, Luh Ayu Tirtayani ${ }^{2}$, Ida Bagus Surya Manuaba ${ }^{3}$ \\ 1,2,3 Jurusan Pendidikan Dasar \\ Universitas Pendidikan Ganesha \\ Singaraja, Indonesia \\ e-mail:niwayanmulandini97@gmail.com¹, ayu.tirtayani@gmail.com², \\ idabagussurya.manuaba@undiksha.ac.id ${ }^{3}$.
}

\begin{abstract}
Abstrak
Penelitian ini bertujuan untuk mengetahui pengaruh metode proyek berbasis pendekatan saintifik terhadap kemampuan motorik halus anak kelompok B di TK Gugus III Kecamatan Tampaksiring. Jenis penelitian ini adalah penelitian semu (quasi eksperimen) dengan rancangan Nonequivalent Control Group Design. Populasi dari penelitian ini adalah seluruh anak kelompok B di TK Gugus III Kecamatan Tampaksiring yang berjumlah 182 anak, yang kemudian dilakukan pengundian untuk mendapatkan 2 sekolah sebagai sampel. Hasil dari penelitian ini menunjukkan rata-rata posttest kemampuan motorik halus pada kelompok ekperimen sebesar 82,12 sedangkan pada kelompok kontrol sebesar 68,82 . Hasil analisis lebih lanjut diperoleh thitung sebesar 7,82 dengan taraf signifikansi $5 \%$ dan $\mathrm{dk}=56$ dengan nilai tabel sebesar 2,000. Berdasarkan analisis data tersebut, ditunjukkan dengan thitung $>t_{\text {tabel }}(7,82>2,000)$ maka $\mathrm{H}_{0}$ ditolak dan $\mathrm{H}_{a}$ diterima. Hal ini membuktikan bahwa terdapat perbedaan yang signifikan kemampuan motorik halus antara anak yang dibelajarkan melalui metode proyek berbasis pendekatan saintifik dengan kelompok anak yang dibelajarkan melalui pembelajaran konvensional. Kesimpulan pada penelitian ini metode proyek berbasis pendekatan saitifik berpengaruh terhadap kemampuan motorik halus pada anak kelompok B di TK Gugus III Kecamatan Tampaksiring.
\end{abstract}

Kata-kata Kunci: metode proyek, pendekatan saintifik, motorik halus, anak usia dini.

\begin{abstract}
This study aims to determine the effect of the project method based on a scientific approach to the fine motor skills of group childrenB in TK Gugus III Kecamatan Tampaksiring.This type of research is quasiexperimental with the design of Nonequivalent Control Group Design. The population of this study were all group children B in TK Gugus III Kecamatan Tampaksiringwhich amounted to 182 children, who then carried out the draw to get 2 schools as samples. The results of this study showed that the average posttest fine motor skills in the experimental group was 82.12 while in the control group it was 68.82 . The results of further analysis obtained tcount of 7.82 with a significance level of $5 \%$ and $\mathrm{dk}=56$ with a table value of 2,000. Based on the analysis of the data, indicated by $t_{\text {count }}>t_{\text {table }}(7.82>2,000)$ then $\mathrm{H}_{0}$ is rejected and $\mathrm{H}_{a}$ is accepted. This proves that there are significant differences in fine motor skills between children who are taught through project methods based on scientific approaches and groups of children who are taught through conventional learning. The conclusion of this study is that the project method based on the scientific approach influences fine motor skills in group childrenB in TK Gugus III Kecamatan Tampaksiring.
\end{abstract}

Keywords: project method, scientific approach, fine motoric, early childhood 


\section{PENDAHULUAN}

Usia dini merupakan masa pertumbuhan yang paling optimal untuk berkembang, pada masa ini hampir seluruh potensi anak mengalami masa peka untuk tumbuh dan berkembang secara cepat. Perkembangan setiap anak tidak sama karena setiap individu memiliki perkembangan yang berbeda.

Seperti yang dicantumkan pada permendikbud Nomor 146 Tahun 2014 "aspek perkembangan anak meliputi aspek kognitif (kemampuan berfikir anak), sosial emosional (interaksi serta perasaan), bahasa (komunikasi), fisik-motorik (motorik kasar dan motorik halus)". Fisik motorik dapat dibagi menjadi dua yaitu motorik kasar adalah keterampilan anak dalam menyeimbangkan tubuhnya, sedangkan motorik halus merupakan keterampilan menggerakkan otot dan fungsinya, gerakan pada motorik halus meliputi menulis, melipat merangkai, menggunting, menempel dan lain sebagainya.

Salah satu aspek yang penting untuk dikembangkan yaitu kemampuan motorik halus. Menurut Feminin (2016:43) "kemampuan motorik halus adalah kesanggupan gerakan yang hanya melibatkan bagian-bagian tubuh tertentu seperti jari-jemari tangan, pergelangan tangan, koordinasi tangan dan mata". Kemampuan motorik halus sangat dibutuhkan oleh anak, karena jika anak memiliki keterampilan motorik yang bagus maka dengan keterampilan tersebut, anak semakin mudah untuk melakukan hal yang diinginkannya.

"Perkembangan motorik halus anak sangat berpengaruh terhadap strategi pembelajaran, termasuk dalam keterampilan" (Nurfarida, 2016:5). Dalam kehidupan seharihari seperti misalnya keterampilan yang menggunakan atau menggerakkan otot-otot kecil anak yang tidak memerlukan tenaga yang kuat, tetapi perlunya koordinasi antara mata dan tangan. Salah satu keterampilan yang menggunakan koordinasi antara mata dan tangan yaitu memindahkan gelas dari meja satu ke meja yang lainnya.Menurut Saptarini (2016:02) "mengembangkan kemampuan motorik halus selain dapat membantu kegiatan sehari hari anak, melatih motorik halus juga dapat mengembangkan kemandirian anak, mengembangkan keterampilan bersosialisasi, dan berguna bagi keterampilan salah satunya memegang pensil".

Maka dari itu anak membutuhkan kegiatan yang menarik untuk dilakukan sehingga dapat melatih kemampuan motorik halus anak. Menurut Hartinah (2018:56) "salah satu kegiatan yang dapat mengembangkan kemampuan motorik halus anak adalah kegiatan mencetak percikan daun". Kegiatan mencetak percikan daun merupakan suatu kegiatan yang menarik dan bermakna bagi anak dimana anak dapat mengatur objek-objek tersebut di atas kertas. Peragaan bagaimana menekan sikat gigi ke seluruh sisir diatas kertas untuk mendapat lukisan percik di atas kertas. Kegiatan mencetak percikan daun tidak hanya dapat mengembangkan kemampuan motorik halus tetapi dalam kegiatan ini anak juga dapat mengenal berbagai macam warna dan bentuk.

Menurut Lestari (2014:5)“mengingat kemampuan motorik halus yang sangat penting, maka kegiatan yang dapat memberikan kesenangan, kreativitas, dan keterampilan pada anak dapat dilakukan dengan menggunakan media playdough". Playdough merupakan adonan lunak dengan berbagai warna yang bisa ditekan-tekan, diremas-remas, dibentuk, dicetak sesuai dengan keinginan dan imajinasi anak. Bermain menggunakan media playdough tidak hanya memberikan kesenangan untuk anak dalam bermain, dalam kegiatan ini dapat melatih otot-otot kecil anak seperti kemampuan anak saat menekan, mencubit, meremas dan membentuk adonan.

Berdasarkan hasil observasi dan wawancara guru di kelompok B TK Gugus III Kecamatan Tampaksiring pada hari Rabu, 27 Februari 2019 ditemukan permasalahan yang 
menunjukkan bahwa anak-anak kelompok B TK Gugus III Kecamatan Tampaksiring memiliki kemampuan motorik halus sangat rendah terutama pada kegiatan mengkoordinasikan mata dan tangan, membedakan figur dan latar belakang, serta kemampuan kosistensi bentuk ini dikarenakan kurangnya perhatian dan pengawasan guru saat proses pembelajaran.

Kegiatan kreatif sangat diperlukan untuk menciptakan suasana belajar yang menyenangkan dan tidak membosankan, sehingga anak aktif dan mau terlibat langsung dalam proses pembelajaran. Pada kenyataannya saat proses pembelajaran berlangsung anak-anak merasa bosan dan kurang aktif dalam proses pembelajaran, serta anak menjadi kurang percaya diri saat mengerjakan tugas dan seringkali meminta bantuan guru atau temannya untuk menyelesaikan tugasnya, ini dikarenakan kurangnya kegiatan kreatif yang dapat memotivasi anak serta menarik perhatian anak untuk belajar.

Agar tercapainya kemampuan motorik halus yang maksimal. Maka sangat penting untuk menerapkan metode pembelajaran yang sesuai dan tepat untuk kebutuhan dan perkembangan anak. Adapun salah satu metode pembelajaran yang dapat digunakan untuk meningkatkan kemampuan motorik halus anak adalah metode proyek. "Metode proyek merupakan salah satu cara yang diajukan dalam meningkatkan kemampuan motorik halus anak" (Mulayati, 2013:3). Melalui metode proyek anak akan lebih mudah untuk mengkoordinasikan gerakan visual motorik seperti mengkoordinasikan gerakan mata dengan tangan, lengan dan tubuh secara bersamaan.

Menurut Elfiga (2017:3) "metode proyek memiliki potensi yang sangat besar untuk membuat pengalaman belajar yang lebih menarik dan bermakna untuk anak-anak". Penggunaan metode proyek ini dapat meningkatkan solidaritas anak dalam mengerjakan suatu kegiatan, karena anak dapat bekerjasama untuk mengerjakan kegiatan agar dapat terselesaikan dengan baik dan kompak.Metode proyek tidak hanya dapat meningkatkan solidaritas anak tetapi juga memberikan wawasan yang luas sehingga anak mendapatkan berbagai pengalaman yang berharga bagi anak.

Fridyastuti (2012:2) "menyatakan bahwa penerapan metode proyek dalam kegiatan pembelajaran dapat dilakukan dengan melibatkan anak secara langsung untuk menyelesaikan suatu tugas atau kegiatan". Pada kegiatan ini anak diberikan kebebasan untuk berkreasi dalam menyelesaikan suatu kegiatan-kegiatan yang mengembangkan motorik halus anak, sehingga kegiatan itu akan menjadi sebuah proyek yang utuh.

Jadi metode proyek merupakan kegiatan yang dapat meningkatkan perkembangan motorik halus anak dengan cara individu ataupun kelompok, dalam kegiatan ini anak dapat melatih motorik halusnya dengan mudah seperti melatih koordinasi mata dan tangan, anak juga dapat bekerjasama dengan teman-temannya untuk menyelesaikan suatu masalah atau kegiatan yang sedang mereka kerjakan.

Dalam penerapannya, metode proyek di kaitkan dengan pendekatan saintifik atau pendekatan berbasis keilmuan dimana pendekatan ini disarankan dalam kurikulum 2013. Pendekatan saintifik diyakini sebagai titian emas perkembangan, keterampilan, dan pengetahuan anak. Pendekatan saintifik merupakan pendekatan pembelajaran yang memberikan kesempatan kepada anak untuk mengeksplorasi serta untuk mengaktualisasikan kemampuannya melalui kegiatan pembelajaran.

Dalam penerapannya, metode proyek di kaitkan dengan pendekatan saintifik atau pendekatan berbasis keilmuan dimana pendekatan ini disarankan dalam kurikulum 2013. Pendekatan saintifik diyakini sebagai titian emas perkembangan, keterampilan, dan pengetahuan anak. Pendekatan saintifik merupakan pendekatan pembelajaran yang 
memberikan kesempatan kepada anak untuk mengeksplorasi serta untuk mengaktualisasikan kemampuannya melalui kegiatan pembelajaran.

Widiastuti (2018:03) "menyatakan bahwa pendekatan saintifik merupakan salah satu langkah mengarahkan anak untuk berfikir saintifis yaitu dengan melibatkan anak secara langsung dalam kegiatan". Melibatkan anak secara langsung, maka anak dapat belajar untuk mengikuti atau melakukan suatu kegiatan, mencari berbagai informasi dengan bertanya, mencari tahu jawaban dengan fakta-fakta yang ditemukan sehingga dapat menyelesaikan suatu kegiatan.

Berdasarkan uraian tersebut maka, dilakukan penelitian eksperimen yang berjudul "Pengaruh Metode Proyek Berbasis Pendekatan Saintifik Terhadap Kemampuan Motorik Halus Anak Kelompok B TK Gugus III Kecamatan Tampaksiring Tahun Pelajaran 2018/2019".

\section{METODE}

Rancangan dari penelitian ini menggunakan penelitian eksperimen semu (quasi eksperimen), dengan menggunakan rancangan Nonequivalent Control Group Desain

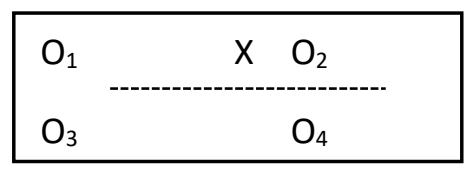

(Sugiyono, 2017:116)

Keterangan:

$\mathrm{O}_{1}=$ Pre-test kelompok eksperimen

$\mathrm{O}_{2}=$ Post-test kelompok eksperimen

$\mathrm{O}_{3}=$ Pre-test kelompok kontrol

$\mathrm{O}_{4}=$ Post-test kelompok kontrol

$\mathrm{X}=$ Perlakuan dengan metode proyek pada

kelompok eksperimen

Pemberian treatment berupa perlakuan metode proyek berbasis saintifik dilakukan di kelompok eksperimen, sedangkan di kelompok kontrol dilaksanakan pembelajaran yaitu metode konvensional. Pre-test dilakukan hanya untuk mengetahui kesetaraan kelompok dengan menganalisis nilai pre-test yang diberikan kepada anak yang mencakup kemampuan motorik halus anak. Post-test dilakukan pada akhir penelitian setelah diberikan perlakuan untuk mendapatkan hasil kemampuan motorik halus di kelompok eksperimen dan kelompok kontrol. Dalam penelitian ini yang diperhitungkan hanya skor post-test saja tanpa memperhitungkan skor pre-test. Hal tersebut dikarenakan pada penelitian ini bertujuan untuk mengetahui pengaruh bukan peningkatan kemampuan motorik halus anak pada kedua kelompok.

Populasi dalam penelitian ini adalah seluruh anak kelompok B di TK Gugus III Kecamatan Tampaksiring. Pupulasi menurutSugiyono (2016:117)merupakan wilayah 
generalisasi yang terdiri atas objek atau subjek yang mempunyai kualitas dan karakteristik tertentu yang ditetapkan oleh peneliti untuk dipelajari kemudian ditarik kesimpulannya".

Data yang diperlukan dalam penelitian ini adalah data terkait kemampuan motorik halus anak, dalam penelitian ini data diperoleh melalui teknik observasi. Langkah ini sangat penting karena data yang dikumpulkan nanti akan digunakan dalam menguji hipotesis. Maka, teknik pengumpulan data harus disesuaikan dengan data yang diperlukan.

Instrumen penelitian dibuat dalam bentuk kisi-kisi kemampuan motorik halus anak serta kisi-kisi kemampuan motorikhalus, tetapi sebelum menerapkan kisi-kisi instrument dilakukan uji coba instrumen yaitu uji validitas isi. Validitas isi yang menyangkut dengan isi dan format instrumen. Validitas isi berkenaan dengan ketepatan instrumen dalam suatu variabel yang akan diukur, serta ketepatan format instrumen. Validitas isi terlebih dahulu akan diuji oleh judgement (dosen penguji) dan kepala TK di Tempat penelitian.

Untuk menganalisis data kemampuan motorik halus anak yang bersifat kuantitatif digunakan statistik uji t. Sebelum dilakukan uji hipotesis terlebih dahulu dilakukan uji prasyarat analisis yaitu uji normalitas sebaran data yang dimaksud untuk mengetahui dapat atau tidaknya melakukan uji hipotesis untuk mengetahui sebaran data skor nilai kemampuan motorik halus anak berdistribusi normal atau tidak sehingga dapat menentukan teknik analisis datanya. Kriteria pengujian adalahuji Chi-Kuadrat $\left(\mathrm{X}^{2}\right)$ pada taraf signifikansi $5 \%$ dan derajat kebebasan $(\mathrm{dk})=\mathrm{n}-1$. Apabila $\mathrm{X}^{2}{ }_{\text {hit }}<\mathrm{X}^{2}$ tabel maka data berdistribusi normal. Untuk mengetahui data tersebut homogeny dapat digunakan uji $F$ dengan kriteria pengujian jika $F_{\text {hitung }}<F_{\text {tabel }}$ maka sampel homogen.

Pada taraf signifikan $5 \%$ dengan pengujian derajat kebebasan untuk pembilang $n_{1}-1$ dan derajat kebebasan untuk penyebut $n_{2}-1$. Sehingga, apa bila $F_{\text {hitung }}<F_{\text {tabel }}$ maka varians antara kelompok ekperimen dengan kelompok kontrol homogeny. Hipotesis yang akan diuji adalah: Untuk membuktikan Ho ditolak, maka harga $t_{\text {hitung }}>t_{\text {tabel, }}$ maka $\mathrm{H}_{0}$ ditolak dan $\mathrm{H}_{a}$ diterima. Pada taraf signifikansi $5 \%$ dengan derajat kebebasan $(d k=n 1+n 2-2)$.

\section{HASIL DAN PEMBAHASAN}

Anak kelompok B1 TK Soma Negara merupakan kelas yang ditetapkan sebagai kelompok eksperimen. Anak padakelompok eksperimen ini terdiri atas 31 anak. Sedangkan anak kelompok B1 TK Ratna Kumara merupakan kelas yang ditetapkan sebagai kelompok kontrol. Anak di kelompok kontrol terdiri dari 27 anak. Anak pada kelompok eskperimen diberikan treatment berupa metode proyek berbasis pendekatan saintifik.

Sedangkan anak pada kelompok kontrol tidak diberikan treatment atau tidak dibelajarkan dengan metode proyek berbasis pendekatan saintifik. Perlakuan di kelompok eksperimen diberikan sebanyak 6 kali dan di kelompok kontrol dilakukan pengontrolan agar tidak dibelajarkan metode proyek berbasis pendekatan saintifik. Setelah itu dilanjutkan dengan pemberian post-test di masing-masing kelompok.

Teknik yang digunakan dalam pengumpulan data post-test adalah non-tes berupa observasi menggunakan lembar observasi kemampuan motorik halus anak. Data yang diperoleh dalam penelitian ini menunjukkan adanya pengaruh metode proyek berbasis pendekatan saintifik terhadap kemampuan motorik halus anak kelompok B di TK Gugus III Kecamatan Tampaksiring Tahun Pelajaran 2018/2019. 
Uji normalitas sebaran data kemampuan motorik halus dilakukan di kelompok eksperimen dan kelompok kontrol. Berikut ini merupakan rekapitulasi hasil uji normalitas sebaran data kelompok eksperimen dan kelompok kontrol disajikan pada tabel 1. berikut ini.

Tabel 1. Hasil Uji Normalitas Sebaran Data

\begin{tabular}{lcccc}
\hline \multicolumn{1}{c}{ Hasil Analisis } & $\mathrm{N}$ & $\mathrm{X}^{2}$ hitung & $\mathrm{X}^{2}$ tabel & Keterangan \\
\hline $\begin{array}{l}\text { Kelompok B1 TK } \\
\text { Soma Negara }\end{array}$ & 31 & 7,94 & 11,07 & $\begin{array}{c}\text { Berdistribusi } \\
\text { normal }\end{array}$ \\
$\begin{array}{l}\text { Kelompok B1 TK } \\
\text { Ratna Kumara }\end{array}$ & 27 & 6,17 & 11,07 & $\begin{array}{c}\text { Berdistribusi } \\
\text { normal }\end{array}$ \\
\hline
\end{tabular}

Berdasarkan perhitungan hasil uji normalitas sebaran data kelompok B1 TK Soma Negara dengan taraf signifikansi $5 \%$ dan dk $=5$ adalah $X^{2}{ }_{\text {hit }}=7,94$ dan $X^{2}$ tabel $=11,07$, karena $X^{2}{ }_{\text {hit }}<X^{2}$ tabel maka data berdistribusi normal. Hal ini berarti skor sebaran data kemampuan motorik halus anak kelompok B1 di TK Soma Negara yang dibelajarkan menggunakan metode proyek berbasis pendekatan saintifik berdistribusi normal. Sedangkan, berdasarkan perhitungan hasil uji normalitas sebaran data nilai kelompok B1 TK Ratna Kumara dengan taraf sifnifikansi $5 \%$ dan $d k=5$ adalah $X^{2}{ }_{\text {hit }}=6,17$ dan $X_{\text {tabel }}^{2}=11,07$, karena $X^{2}{ }_{\text {hit }}<X^{2}$ tabel maka data berdistribusi normal. Hal ini berarti skor sebaran data kemampuan motorik halus anak kelompok B di TK Ratna Kumara yang dibelajarkan menggunakan pembelajaran konvensional berdistribusi normal.

Selanjutnya dilakukan uji homogenitas varians berdasarkan data kemampuan motorik halus anak yang dibelajarkan melalui metode proyek berbasis pendekatan saintifik dan yang tidak dibelajarkan metode proyek berbasis pendekatan saintifik. Jumlah kelompok eksperimen 31 anak dan kelompok kontrol 27 anak, untuk menentukan homogenitas varians digunakan uji $\mathrm{F}$, berikut ini akan disajikan pada tabel 2.

Tabel 2. Uji Homogenitas Varians Kelompok Eksperimen dan Kontrol

\begin{tabular}{lllllll}
\hline \multicolumn{1}{c}{ Sampel } & Mean & SD & Varians & $F_{\text {hitung }}$ & $F_{\text {tabel }}$ & Kesimpulan \\
\hline $\begin{array}{l}\text { Kelompok } \\
\begin{array}{l}\text { Eksperimen } \\
\text { Kelompok }\end{array}\end{array}$ & 82,12 & 7,01 & 49,11 & 1,51 & 1,90 & Homogen \\
\begin{tabular}{l} 
Kontrol \\
\hline
\end{tabular} & 68,82 & 5.70 & 32,54 & & & \\
\hline
\end{tabular}

Berdasarkan tabel 2. Nilai Ftabel pada taraf signifikansi $5 \%$ dengan derajat kebebasan $(\mathrm{dk}$ pembilang $=30$ dan dk penyebut $=26)=1,90$ dan hasil analisis $F_{\text {hitung }}<F_{\text {tabel }}$ maka varians antara kelompok eksperimen dengan kelompok kontrol homogen.

Berdasarkan hasil uji normalitas sebaran data dan uji homogenitas varians diperoleh bahwa data kedua kelompok berdistribusi normal dan varians kedua kelompok homogen. 
Berdasarkan data tersebut maka uji statistik yang digunakan dalam penelitian ini adalah uji beda mean (uji t). Hasil perhitungan uji hipotesis disajikan dalam tabel 3 berikut ini.

Tabel 3. Uji Hipotesis Kelompok Eksperimen dan Kelompok Kontrol

\begin{tabular}{lccccccc}
\hline \multicolumn{1}{c}{ Sampel } & $\mathrm{N}$ & Dk & Mean & Varians & $t_{\text {hitung }}$ & $t_{\text {tabel }}$ & Kesimpulan \\
\hline $\begin{array}{l}\text { Kelompok } \\
\text { Eksperimen }\end{array}$ & 31 & 56 & 82,12 & 49,11 & 7,82 & 2,000 & $\mathrm{H}_{\text {o ditolak }}$ \\
& & & & & & \\
$\begin{array}{l}\text { Kelompok } \\
\text { Kontrol }\end{array}$ & 27 & & 68,82 & 32,54 & & & \\
\end{tabular}

Berdasarkan tabel 3 maka diperoleh thitung $=7,82$ sedangkan pada taraf signifikansi $5 \%$ diperoleh nilai ttabel $=2,000$ sehingga thitung $>$ ttabel. Berdasarkan hasil tersebut, maka dapat disimpulkan bahwa Ho menyatakan "tidak terdapat perbedaan yang signifikan kemampuan motorik halus antara kelompok anak yang dibelajarkan menggunakan metode proyek berbasis pendekatan saintifik dengan kelompok anak yang tidak dibelajarkan menggunakan metode proyek berbasis pendekatan saintifik pada anak kelompok B di TK Gugus III Kecamatan Tampaksiring Tahun Pelajaran 2018/2019", ditolak.

Perolehan hasil perhitungan analisis data yang dilakukan menunjukkan bahwa nilai rata-rata anak yang dibelajarkan dengan pembelajaran menggunakan metode proyek berbasis pendekatan saintifik 82,12 dan anak yang mengikuti pembelajaran konvensional 68,82 . Hasil temuan pada penelitian ini menunjukkan bahwa pembelajaran dengan menggunakan metode proyek berbasis pendekatan saintifik berpengaruh terhadap kemampuan motorik halus anak.

Hal ini disebabkan metode proyek berbasis pendekatan saintifik merupakan kegiatan pembelajaran yang dapat melatih kemampuan motorik halus anak dengan cara melibatkan anak secara langsung untuk belajar memecahkan masalah dalam menyelesaikan suatu tugas atau kegiatan, dalam kegiatan metode proyek berbasis pendekatan saintifik masingmasing anak melakukan bagian tugasnya secara individual atau dalam kelompok kecil untuk mencapai tujuan bersama. Kegiatan pembelajaran menggunakan metode proyek berbasis pendekatansaintifik dapat menciptakan suasana belajar yang aktif dan kratif sehingga anak termotifasi untuk mengenal lebih banyak kegiatan.

Terdapat beberapa manfaat metode proyek menurut Mursid (2017:31) diantaranya: 1) Memberikan pengalaman kepada anak dalam mengatur dan mendistribusikan kegiatan, 2) Belajar bertanggung jawab terhadap pekerjaan masing-masing, 3) Memupuk semangat gotong royong, 4) Memberikan kesempatan kepada anak untuk mengekspresikan pola pikir, keterampilan, serta kemampuannya untuk menyelesaikan sejumlah permasalahan yang mereka hadapi. Selain itu, menurut Moeslichatoen (2004:151) ada tiga tahap yaitu kegiatan awal, kegiatan pengembangan dan kegiatan penutup.

Menggunakan metode pembelajaran proyek berbasis pendekatan saintifik memperoleh respon yang sangat positif dari anak ketika proses pembelajaran berlangsung. 
Pada saat pembelajaran berlangsung anak-anak sangat aktif mampu untuk bekerjasama agar dapat memecahkan suatu permasalahan sehingga anak mendapatkan pengetahuan yang baru berdasarkan pengalamannya dalam memecahkan suatu permasalahan. Hal ini sesuai dengan teori yang dikemukakan olehRusman (2017:397) menyatakan bahwa pembelajaran proyek merupakan metode belajar yang menggunakan masalah sebagai langkah awal dalam mengumpulkan dan mengintegrasikan pengetahuan baru berdasarkan pengalamannya dalam beraktifitas secara nyata.

Berbeda dengan kelompok kontrol kegiatan pembelajaran konvensional yang hanya menggunakan kegiatan yang menoton sehingga anak menjadi bosan dan sering kali tidak memperhatikan guru. Pembelajaran yang kurang kreatif serta kurangnya memanfaatkan media pembelajaran mengakibatkan anak menjadi kurang fokus dalam kegiatan pembelajaran.

Penelitian ini hanya terbatas pada kemampuan motorik halus anak. Kemampuan motorik halus anak sangat penting, ini disebabkan karena baik secara langsung maupun tidak langsung akan mempengaruhi perilaku anak sehari-hari. Perkembangan fisik motorik sangat berperan penting bagi seorang anak, karena selain melatih kelincahan dan kecekatan, juga dapat memberikan motivasi kepada anak dalam berinteraksi dengan lingkungan. Melatih kemampuan motorik halus sejak dini bertujuan untuk anak akan belajar memanfaatkan otot-otot kecilnya supaya ketika melakukan suatu kegiatan anak tidak lagi mengalami kesulitan.

Pembelajaran menggunakan metode proyek berbasis pendekatan saintifik terhadap kemampuan motorik halus anak akan memberikan pengalaman serta kesempatan kepada anak untuk dapat meningkatkan kemampuan motorik halusnya melalui kegiatan pembelajaranyang kreatif, menyenangkan, dan dapat meningkatkan rasa ingin tahu anak untuk mendapatkan informasi yang bermanfaat untuk kedepannya.

Dengan demikian, terdapat pengaruh metode proyek berbasis pendekatan saintifik terhadap kemampuan motorik halus pada anak kelompok B di TK Gugus III Kecamatan $\begin{array}{lll}\text { Tampaksiring Tahun 2018/2019. } & \text { Pelajaran }\end{array}$

Tabel 4.

Data Kemampuan Motorik Halus Anak Kelompok Eksperimen dan Kelompok Kontrol

\begin{tabular}{|c|c|c|}
\hline Hasil Analisis & $\begin{array}{c}\text { Kelompok } \\
\text { Eksperimen }\end{array}$ & $\begin{array}{l}\text { Kelompok } \\
\text { Kontrol }\end{array}$ \\
\hline Mean & 82,12 & 68,82 \\
\hline Standar Deviasi & 7,01 & 5,70 \\
\hline Varians & 49,11 & 32,54 \\
\hline Skor Maksimum & 96,14 & 80,22 \\
\hline Skor Minimum & 61,09 & 51,72 \\
\hline
\end{tabular}

Berdasarkan hal tersebut, maka uji statistik yang digunakan dalam penelitian ini adalah uji t dengan menggunakan rumus uji varians. Setelah perhitungan selesai kemudian dilakukan uji signifikasi yaitu dengan cara membandingkan antara thitung yang diperoleh dan 
Mulandini, dkk. Vol. 7(1), 2019

$t_{\text {tabel. }}$. Dengan kriteria jika harga $t_{\text {hitung }} \leq$ dari harga $t_{\text {tabel, }}$, maka $\mathrm{H}_{\circ}$ diterima dan $\mathrm{H}_{\mathrm{a}}$ ditolak, dan jika $t_{\text {hitung }} \geq t_{\text {tabelmaka }} \mathrm{H}_{\mathrm{o}}$ ditolak dan $\mathrm{H}_{\mathrm{a}}$ diterima. Pada taraf signifikansi $5 \%$ dengan $\mathrm{dk}=\mathrm{n}-1$. 
Dari data tersebut menunjukkan bahwa $t_{\text {hitung }}>t_{\text {tabel, }}$ dimana $t_{\text {hitung }}=7,82$ dan $t_{\text {tabel }}=2,000$, maka Ho ditolak dan Ha diterima. Pada taraf signifikansi $5 \%$ dengan dk $=n-1$. Jadi data tersebut menunjukkan bahwa kemampuan motorik halus anak kelompok B yang dibelajarkan menggunakan metode proyek berbasis pendekatan saintifik memiliki rata-rata yang lebih tinggi sedangkan kelompok B yang tidak dibelajarkan menggunakan metode proyek berbasis pendekatan saintifik memiliki rata-rata yang rendah. Dari hasil analisis uji hipotesis yang dilaksanakan diperoleh hasil yang disajikan pada tabel 4 .

\section{PENUTUP}

Berdasarkan hasil penelitian dan pembahasan, maka dapat ditarik simpulan bahwa metode proyek berbasis pendekatan saintifik terhadap kemampuan motorik halus anak kelompok B di TK Gugus III Kecamatan Tampaksiring, hal ini terbukti dari hasil rata-rata kelompok yang dibelajarkan dengan menggunakan metode proyek berbasis pendekatan saintifik (kelompok ekperimen) diperoleh rata-rata sebesar 82.12, sedangkan pada kelompok yang dibelajarkan dengan pembelajaran konvensional (kelompok kontrol) diperoleh rata-rata sebesar 68.82. Rerata kemampuan motorik halus pada anak yang dibelajarkan melalui metode proyek berbasis saintifik lebih tinggi disbanding dengan anak yang dibelajarkan menggunakan metode konvensional. Berdasarkan hasil analisis menggunakan uji-t diperoleh $t_{\text {hitung }} 7.82$ dengan taraf signifikan $5 \%$ dan $(\mathrm{dk}=56)$, maka diperoleh $\mathrm{t}_{\text {tabel }} 2.000$ sehingga $\mathrm{t}_{\text {hitung }} 7.82 \geq \mathrm{t}_{\text {tabel }}$ 2.000 , sehingga terdapat pengaruh metode proyekterhadap kemampuan motorik halus anak kelompok B di TK Gugus III Kecamatan Tampaksiring Tahun Pelajaran 2018/2019.

Berdasarkan simpulan dari penelitian ini, maka hasil penelitian ini dapat dipakai sebagai kajian penelitian relevan yang bermanfaat untuk meneliti tentang pengaruh metode proyekberbasis pendekatan saintifik terhadap kemampuan motorik halus anak.

\section{DAFTAR PUSTAKA}

Elfiga, Fedila. 2017. "Pengaruh Metode Proyek Terhadap Kemampuan Motorik Halus Anak Usia 5-6 Tahun Di PAUD AT-TAMIMI Kecamatan Tampan Kota Pekanbaru". Jurnal Online Mahasiswa, volume4 No. 1, halaman (1-14). Tersedia pada https://www.neliti.com/id/publications/206435/pengaruh-metode-proyek-terhadap-

kemampuan-motorik-halus-anak-usia-5-6-tahun-di-p. (Diakses pada tanggal 10 Desember 2018).

Feminin, Kuntum. 2016. "Upaya Meningkatkan Kemampuan Motorik Halus Pada AUD Melalui Kegiatan Bermain Konstruksi Plastisin Bentuk Huruf Kelompok B RA TAQWAL ILAH Semarang Tahun Ajaran 2015/2016", halaman (32-45). Tersedia pada http://journal.upgris.ac.id/index.php/paudia/article/view/1173. (Diakses pada tanggal 29 Maret 2018).

Fridyastuti, Renty. 2012. "Pengaruh Metode Proyek Terhadap Kemampuan Motorik Halus Pada Anak Kelompok A Di TK PSM II Takeran Magetan". Jurnal IImiah Pendidikan, volume 2 No.3, halaman (1-6). Tersedia pada https://jurnalmahasiswa.unesa.ac.id/index.php/paudteratai/article/view/4023. (Diakses pada tanggal 10 Desember 2018).

Hartinah, Ulfa. 2018. "Efektifitas Mencetak Percikan Daun Terhadap Perkembangan Motorik Halus Anak Di Taman Kanak-kanak Aisyiyah Suayan". Jurnal Usia Dini, volume 4 no. 2, halaman (55-66). 
Lestari, Sri. 2014. "Pengembangan Kemampuan Motorik Halus Melalui Bermain Playdough Pada Anak Kelompok B Di Kb Hudalloh Bekelan Karangnongko Klaten Tahun Pelajaran 2013/2014". Naskah Publikasi. Tersedia pada http://eprints.ums.ac.id/30127/17/NASKAH PUBLIKASI.pdf. (Diakses pada tanggal 2 Maret 2019).

Moeslichatoen. 2004. Metode Pengajaran Di Taman Kanak-kanak. Jakarta: PT RINEKA CIPTA.

Mulayati, Siti. 2013. "Meningkatkan Kemampuan Motorik Halus Anak Melalui Metode Proyek Usia 5-6 Tahun Di PAUD Tunas Mekar Kecamatan Senapelan Kota Pekanbaru", halaman(1-7). Tersedia pada https://repository.unri.ac.id/xmlui/bitstream/handle/123456789/5227/3.SITI MULYATI.pdf?sequence=1\&isAllowed=y. (Diakses pada tanggal 14 Juli 2019).

Mursid. 2017. Pengembangan Pembelajaran PAUD. Bandung: PT REMAJA ROSDAKARYA.

Nurfarida, Anis. 2016. "Mengembangkan Kemampuan motorik Halus Dengan Membentuk Buah Melalui Media Playdough Pada Kelompok A TK PGRI Kepuhrejo Di Kabupaten Tulungagung Tahun Pelajaran 2015/2016". Artikel Skripsi Universitas Nusantara PGRI Kediri, halaman (19). Tersedia padahttp://simki.unpkediri.ac.id/mahasiswa/file artikel/2016/12.1.01.11.0296.pdf. (Diakses pada tanggal 13 Mei 2017).

Rusman. 2017. Belajar dan Pembelajaran Berorientasi Standar Proses Pendidikan. Jakarta: Kencana.

Saptarini, Indah. 2016. "Peningkatan Kemampuan Motorik Halus Melalui Project Based Learning Pada Anak Kelompok B TK Siwi Peni XI Laweyan Tahun Ajaran 2015/2016". Tersedia padahttp://jurnal.fkip.uns.ac.id/index.php/paud/article/download/8612/6354. (Diakses pada tanggal 14 Juli 2019).

Sugiyono. 2016. Metode Penelitian Pendidikan Pendekatan Kuantitatif, Kualitatif, dan R\&D. Bandung: Alfabeta.

Widiastuti, Erma. 2018. Pengaruh Pendekatan Saintifik Terhadap Kemampuan Pemecahan Masalah Pada Anak Kelompok B Di Taman Kanak-Kanak.E-Journal Pendidikan Anak Usia Dini Universitas Pendidikan Ganesha Jurusan Pendidikan Guru Pendidikan Anak Usia Dini, Volume 6 No.

2. padahttps://ejournal.undiksha.ac.id/index.php/JJPAUD/article/view/15314/9334. pada tanggal 13 Desember 2018).
Tersedia (Diakses 